"Mircea cel Batran" Naval Academy Scientific Bulletin, Volume XIX - 2016 - Issue 1

Published by "Mircea cel Batran" Naval Academy Press, Constanta, Romania // The journal is indexed in:

PROQUEST / DOAJ / DRJI / JOURNAL INDEX / I2OR / SCIENCE LIBRARY INDEX / Google Scholar / Crossref /

Academic Keys / ROAD Open Access / OAJI / Academic Resources / Scientific Indexing Services / SCIPIO

\title{
MODELLING OF HYDRO-METEOROLOGICAL PARAMETERS USING SPOS SOFTWARE IN ORDER TO OPTIMIZE NAVIGATIONAL ROUTES
}

\author{
Dinu ATODIRESEI ${ }^{1}$ \\ Florin NICOLAE ${ }^{2}$ \\ Mihail PRICOP ${ }^{3}$ \\ Alexandru SERBAN ${ }^{4}$ \\ Adrian ALDEA ${ }^{5}$ \\ ${ }^{1}$ Adv. Instructor, PhD, Department of Maritime and River Navigation and Transportation ,,Mircea cel Batran" \\ Naval Academy, Constanta, Romania, dinu.atodiresei@anmb.ro \\ ${ }^{2}$ Associate Professor Eng., PhD, Department of Naval and Port Engineering and Management, ,,Mircea cel \\ Batran" Naval Academy, Constanta, Romania, florin.nicolae@anmb.ro \\ ${ }^{3}$ Associate professor Eng., PhD, Department of Maritime and River Navigation and Transportation ,,Mircea \\ cel Batran" Naval Academy, Constanta, Romania, mihail.pricop@anmb.ro \\ ${ }^{4}$ Student Department of Maritime and River Navigation and Transportation ,Mircea cel Batran” Naval \\ Academy, Constanta, Romania, alexandru.serban@student.anmb.ro \\ ${ }^{5}$ Student Department of Maritime and River Navigation and Transportation ,,Mircea cel Batran” Naval \\ Academy, Constanta, Romania,
}

Abstract: The purpose of this paper is to analyze the advantages of adjusting the navigational routes not only based on geographical hazards but also according to hydro-meteorological parameters with the purpose of creating a route with maximum efficiency. The Ship Performance Optimization System (SPOS) used by vessels is one of the best onboard weather routing systems. In a competitive market such as the one today, it is essential to use such software so that the ship's route can be optimized, taking into account sea conditions such as waves, current and swell, wind and other weather elements. Other benefits include a decreased risk of environmental pollution caused by ships unprepared for certain adverse weather conditions.

Keywords: Hydro-meteorological parameters, SPOS, Ship Performance, meteorology, route optimization, meteorological software

\section{Introduction}

\subsection{Shipping industry dependence to oil}

The reason shipping and charter companies have to be so careful when planning their strategy according to oil prices is that according to a market research entitled "Bunker Fuel Market Global Industry Analysis, Size, Share, Growth, Trends, and Forecast 2014 - 2020" - depending on the shipping sector, at least $70 \%$ of all operational costs of a vessels comes from fuel costs. Therefore, shipping operators are ready to go to great lengths to make sure they reduce the fuel cost as much as possible [1].

Additionally the International Maritime Organization - IMO intends on reducing the amount of carbon dioxide, sulfur dioxide, carbon monoxide, and other greenhouse gasses. According to their research individual ships are expected to reduce their output emissions by $25-$ $75 \%$.

There is no study to predict that the shipping industry will, by any measure reduce, its major importance in the global transport of goods. Nevertheless, by 2030 IMO believes that the entire industry could reduce the output of greenhouse gasses by $50 \%$ with zero net cots.

In order to achieve this target IMO has introduced as mandatory under MARPOL Annex VI a number of technical and operational measures [2] that include:

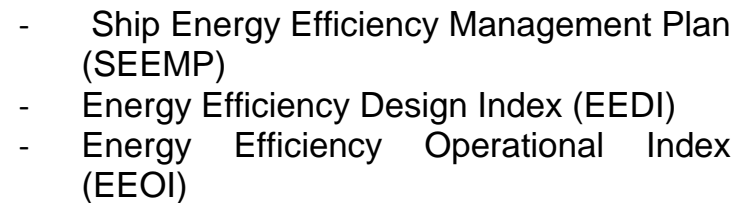

\subsection{Economic climate}

In the last decade the fuel costs have spiked several times. Firstly in 2008 at over $\$ 145 / \mathrm{b}$ and multiple times in subsequent years although not at values of similar height as in 2008 . One reason for gentler spikes is the discovery and improvement of new sources of extraction like shale "fracking" technology (in Nebraska, North Dakota and Alberta) and extraction of oil from oil sands/bituminous sands - Canada, Kazakhstan and Russia. 
"Mircea cel Batran" Naval Academy Scientific Bulletin, Volume XIX - 2016 - Issue 1

Published by "Mircea cel Batran" Naval Academy Press, Constanta, Romania // The journal is indexed in: PROQUEST / DOAJ / DRJI / JOURNAL INDEX / I2OR / SCIENCE LIBRARY INDEX / Google Scholar / Crossref /

Academic Keys I ROAD Open Access / OAJI / Academic Resources / Scientific Indexing Services / SCIPIO

On January 20, 2016 the oil prices reached the lowest point in 13 years - \$26.55/b (Figure 1).
The current price of oil is slowly recovering, currently being approximately $\$ 45 / \mathrm{b} \quad[3]$.

\section{WTI Crude Oil Spot Price}

\section{Current market price in USD per barrel}

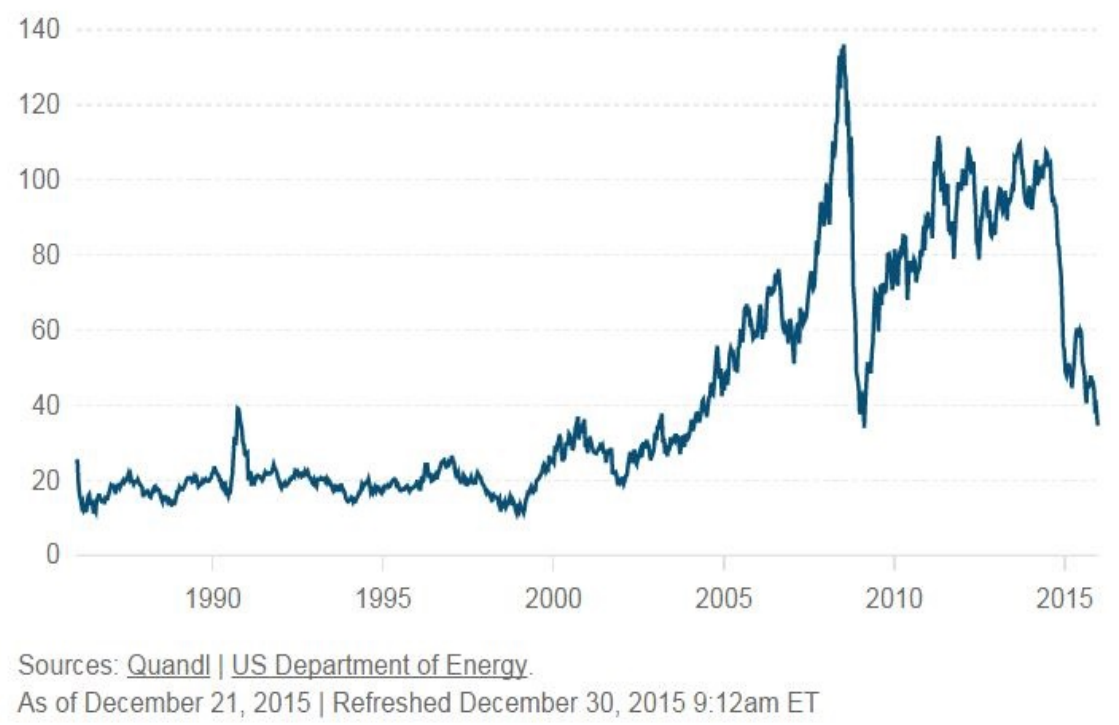

Figure 1 - Crude Oil Price USD/barrel [4]

Despite the current price, the shipping industry must always look towards the future in order to predict future fluctuations. For that reason forecasts like that predicted by USA - Energy Information Administration (EIA) have predicted that OPEC countries and Russia wish to keep the oil prices at least around \$70/b. Additionally Iran's sanctions have been lifted, therefore this major exporter will now also be allowed to trade on international markets. Furthermore, the large deposits of crude oil located in Canada and USA which are extracted from bituminous sands or using shale "fracking" technology, become profitable at $\$ 70-80 / \mathrm{b}$.

Having taken all this under consideration EIA has predicted that the price will rapidly increase to above $\$ 70 / \mathrm{b}$ but will not increase over $\$ 100 / \mathrm{b}$ between 2020 and 2040.

\subsection{Hypothesis of the research}

All this new implementations of regulations, as well as new engine upgrades are vastly dependent, in order to work and be economically feasible, on the crew's ability to predict the date the ship will reach the next port of call. Large vessels, undergoing global voyages need to be able to predict the hydro-meteorological parameters. These influence not only the safety of the ship, cargo and crew onboard, but can also have a major impact on the fuel efficiency.
Although the industry stands to gain major profit from route optimization (and in the shipping industry these benefits are in the range of billions of dollars) the market for hydro-meteorological optimization and weather forecasting is quite small in terms of the numbers of software available on the market.

One such software is the Ship Performance Optimization System (SPOS). This software has highly customizable functions according to ship's particulars which enable the program to optimize the route considering the influence of waves, wind, current and swell and other weather elements.

SPOS is essentially a software. It represents only the user interface which a company called MeteoGroup is using to transmit its data towards the vessels which have a subscription to their service.

MeteoGroup is the largest weather forecasting service in Europe, however its client base spans around the globe, being a key player within the industry in USA and Asia. These high quality services are provided by a team of over 100 meteorologists who provide their clients with a constant feed of data. Although, it is advisable for the ships to use SPOS and internet connection to get a better view of the forecast, companies managing vessels with small internet bandwidth 
"Mircea cel Batran" Naval Academy Scientific Bulletin, Volume XIX - 2016 - Issue 1

Published by "Mircea cel Batran" Naval Academy Press, Constanta, Romania // The journal is indexed in: PROQUEST / DOAJ / DRJI / JOURNAL INDEX / I2OR / SCIENCE LIBRARY INDEX / Google Scholar / Crossref /

Academic Keys / ROAD Open Access / OAJI / Academic Resources / Scientific Indexing Services / SCIPIO

can choose to have the data send to the vessel by e-mail.

\section{Methods used to assess the efficiency of} the program:

\subsection{Basic principles of SPOS}

Once the software is installed onboard the program will need a set of parameters to be defined. These parameters are generally constant during the operation of the ship and include: hull dimensions, engine fuel consumption curve (Figure 2) depending on rpm and actual speed in calm water (with various degrees of loading).

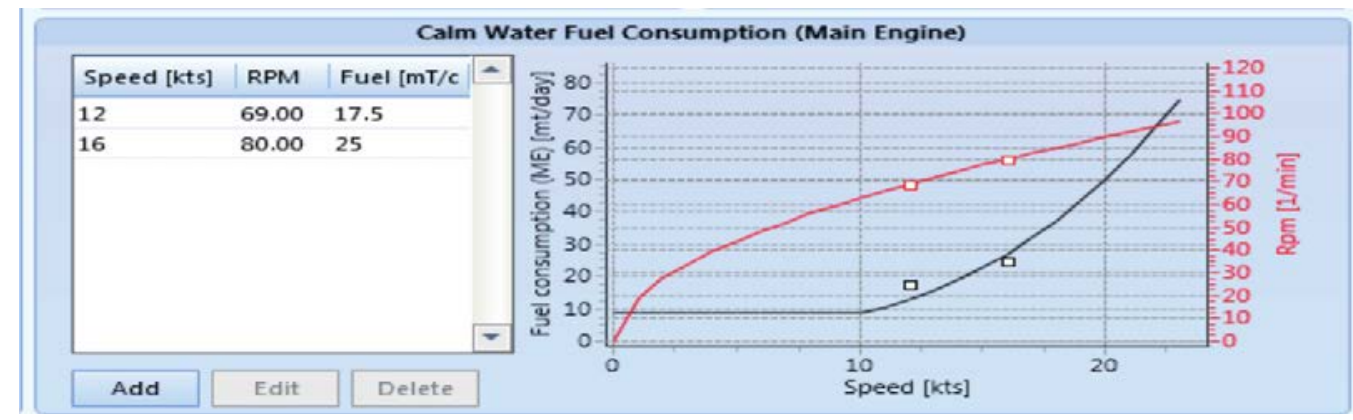

Figure 2 - Calm water fuel consumption curve for the main engine

Another useful parameter is to indicate the program if the ship's engine has a WHR (Figure 3) - waste heat recovery plant - therefore determining if the vessel is capable of dual speed strategy. However, in order to use this method the captain has to be able to predict with very high accuracy the way the environment will influence his ship's speed; otherwise this method can end up delaying the vessel unnecessarily or consuming more fuel due to acceleration on the last leg of the voyage.

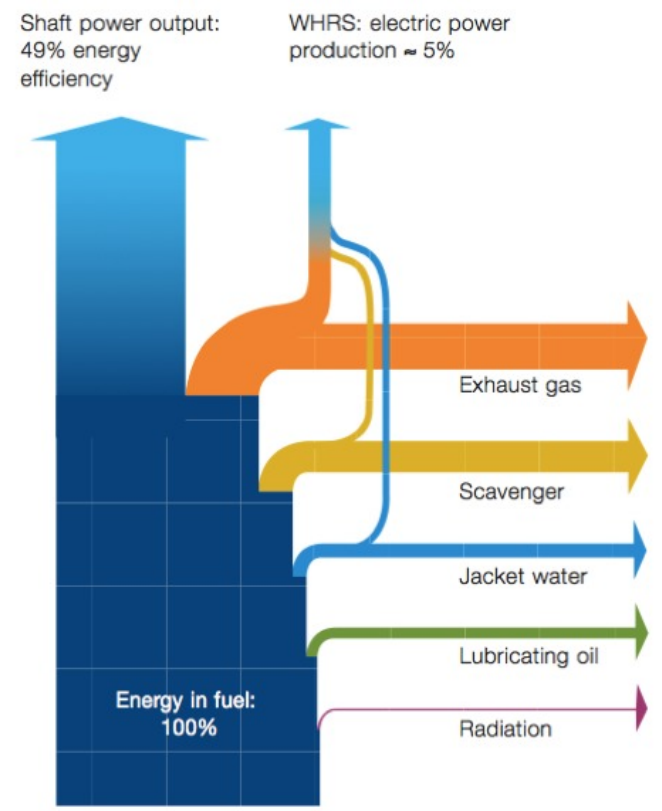

Figure 3 - Waste heat recovery system - WHS

On modern vessels SPOS will be integrated with ECDIS. By merging these two technologies the navigational officer or the captain can make better decisions based on possible alternative routes. By 
"Mircea cel Batran" Naval Academy Scientific Bulletin, Volume XIX - 2016 - Issue 1

Published by "Mircea cel Batran" Naval Academy Press, Constanta, Romania // The journal is indexed in: PROQUEST / DOAJ / DRJI / JOURNAL INDEX / I2OR / SCIENCE LIBRARY INDEX / Google Scholar / Crossref /

Academic Keys / ROAD Open Access / OAJI / Academic Resources / Scientific Indexing Services / SCIPIO

altering the route the vessel can stay clear of hurricanes, tropical storms, ice patches (Figure 4) or icebergs, also it can calculate and indicate the most efficient way to avoid bad weather. According to research $80-90 \%$ of naval accidents happen because of human factor. [5]

In this paper we will discuss these topic but also the software's computing power of showing an

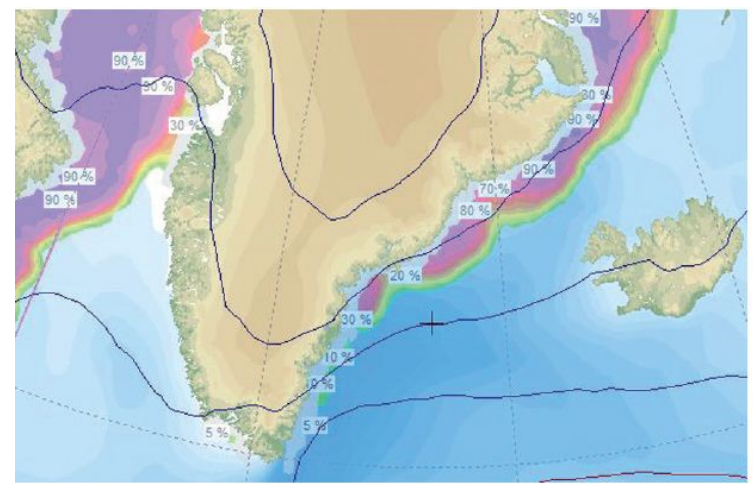

\begin{tabular}{|c|c|}
\hline GREEN & $5-9 \%$ \\
\hline LIGHT GREEN & $10-19 \%$ \\
\hline YELLOW & $20-29 \%$ \\
\hline SAND & $30-39 \%$ \\
\hline BROWN & $40-49 \%$ \\
\hline BROWN/RED & $50-59 \%$ \\
\hline ORANGE & $60-69 \%$ \\
\hline RED & $70-79 \%$ \\
\hline PINK & $80-89 \%$ \\
\hline LILA & $90-100 \%$ \\
\hline GREY & UNDEFINED \\
\hline
\end{tabular}

Figure 4 - Ice concentration map displayed in SPOS

\subsection{SPOS Routing}

Here is where it all starts by selecting between: Voyage template

- User defined route templates.

Additionally the user has to input the expected departure time.

There are two main types of route calculation (Figure 5):

-Shortest time - used in case the vessel is on a deadline - for example reaching entry into Suez alternative route in order to maximize the fue efficiency. It does this by calculating the influence the wind, waves, swell and current will have on the vessel.

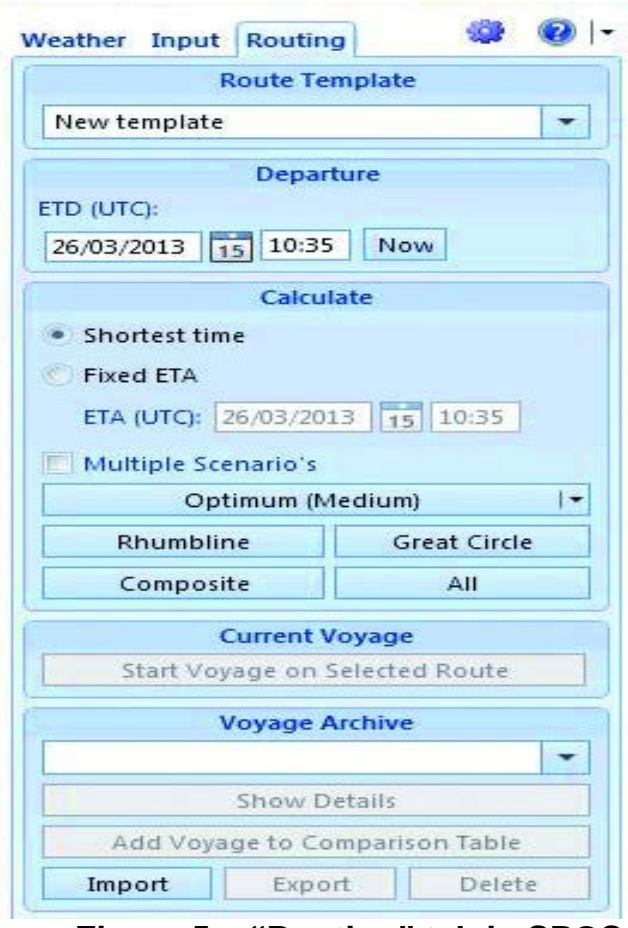

Figure 5 - "Routing" tab in SPOS 
"Mircea cel Batran" Naval Academy Scientific Bulletin, Volume XIX - 2016 - Issue 1

Published by "Mircea cel Batran" Naval Academy Press, Constanta, Romania // The journal is indexed in: PROQUEST / DOAJ / DRJI / JOURNAL INDEX / I2OR / SCIENCE LIBRARY INDEX / Google Scholar / Crossref /

Academic Keys I ROAD Open Access / OAJI / Academic Resources / Scientific Indexing Services / SCIPIO

It is possible to calculate the route taking into consideration loxodromic or orthodromic movement. For this reason the software care make adjustments by rhumb line, composite track, great circle, or a combination of these three. Current voyage, tab can be used to initialize the

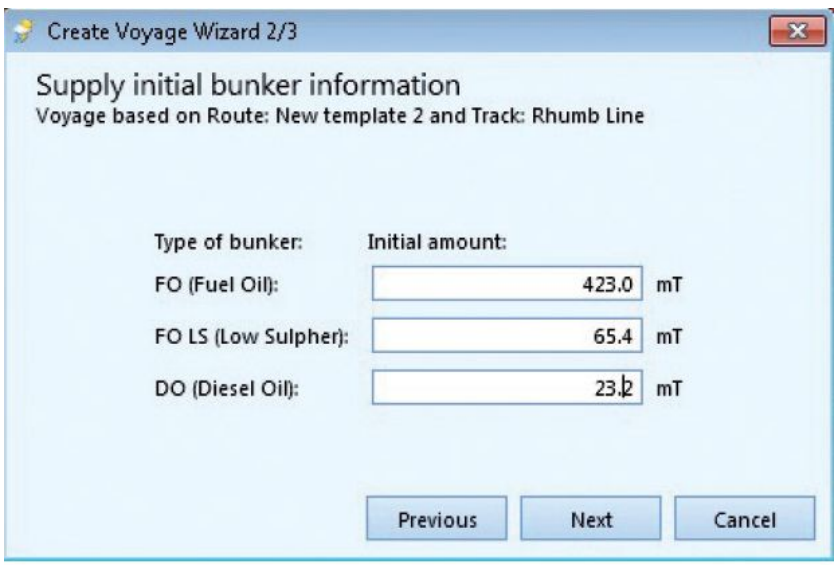

Figure 6 - Initial bunker

\section{Results}

3.1 Case study - New Orleans USA to Rossvatnet Norway

In this paper we followed the results of a voyage executed by a small container vessel (1000 TEU) charted to transport goods on the route mentioned above. There were two main problems, firstly the ship had to make the voyage with a low amount of voyage. In order to do this SPOS will request additional data in order to calculate optimum efficiency of fuel: draft (fwd/aft), total tons of cargo (Figure 7), total tons of diesel, low sulfur and high sulfur fuel (Figure 6).

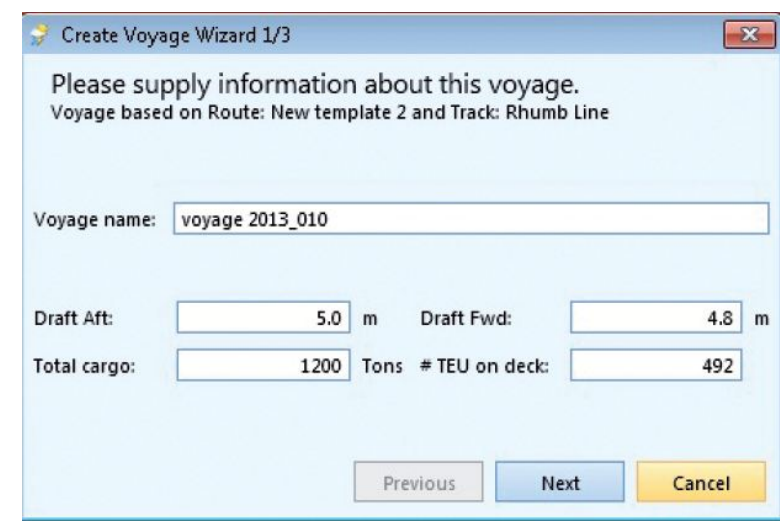

Fig. 7 - Initial information about load

fuel and secondly, due to the small size of the ship, large storms were to be avoided as much as possible. The captain was aware that there were two main possibilities (Figure 8) :

a) USA - Azores - English Channel and then going north, using Kiel Canal - we will call this - Route A

b) Along the North American coast, and then across the northern Atlantic Ocean route $B$

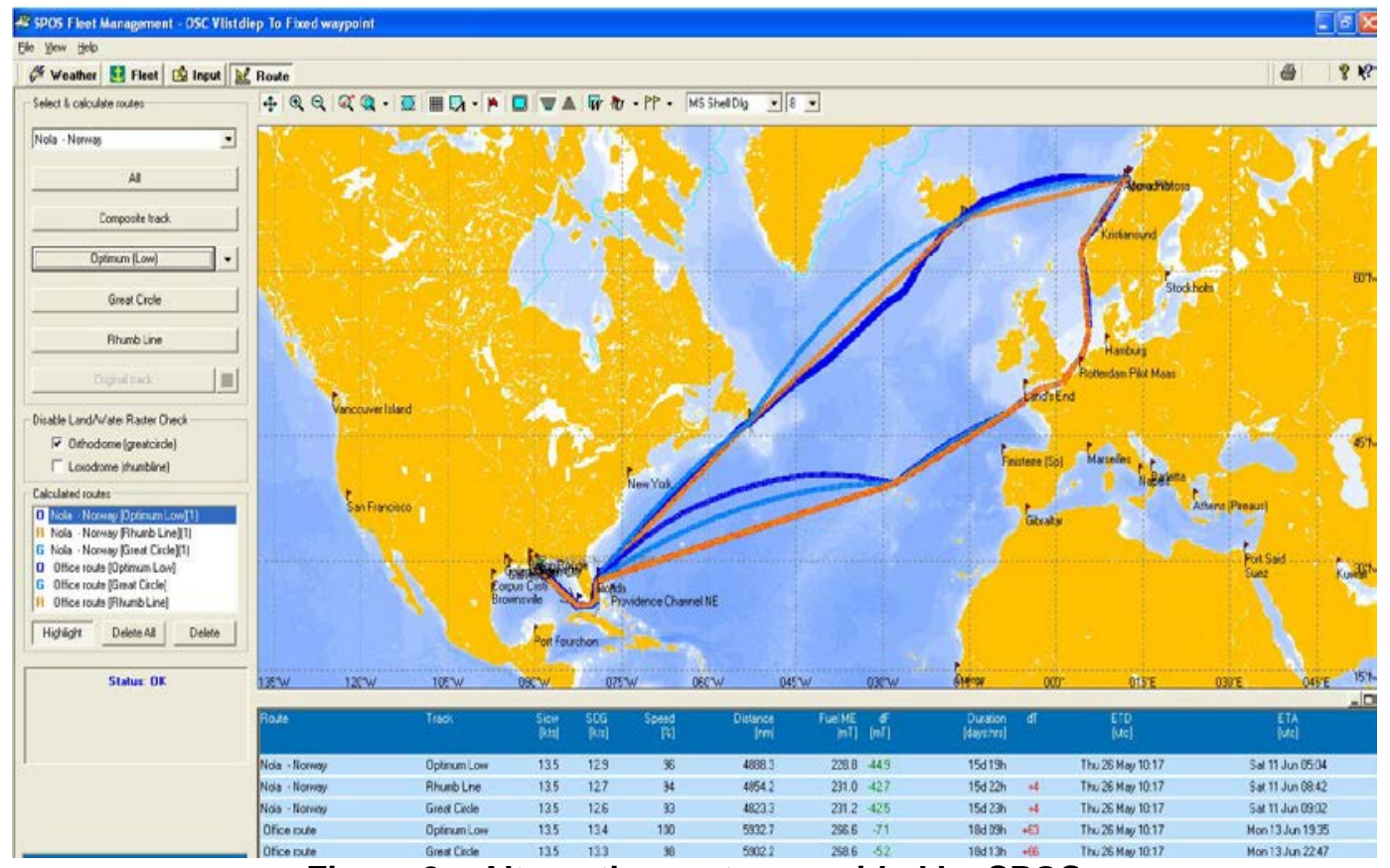

Figure 8 - Alternative routes provided by SPOS 
"Mircea cel Batran" Naval Academy Scientific Bulletin, Volume XIX - 2016 - Issue 1

Published by "Mircea cel Batran" Naval Academy Press, Constanta, Romania // The journal is indexed in: PROQUEST / DOAJ / DRJI / JOURNAL INDEX / I2OR / SCIENCE LIBRARY INDEX / Google Scholar / Crossref /

Academic Keys / ROAD Open Access / OAJI / Academic Resources / Scientific Indexing Services / SCIPIO

As we mentioned before each route ( $A$ or $B$ ) had multiple variations depending or Hydrometeorological parameters, and Rhumb Line, Great Circle or composite track. By using the automatic updates of SPOS the captain was able to receive data every hour regarding the weather. This way the officer in charge of the watch could determine if the weather became too rough. Moreover, using the GuardZone feature (colloquially called "motion limits") of SPOS the Captain inputted the kind of weather he believed the ship will no longer be safe to navigate in (Figure 9).

Using SPOS it was determined that the optimum speed was $13.5 \mathrm{Kts}$, constant speed, for the entire length of the voyage. This speed was then transformed by SPOS in actual RPM - 55RPM. This value which could be easily transmitted to the engine room allowed for a better understanding of what parameters had to be adjusted in order to reach the destination in time.

It is well known that an average SOG - speed over ground is not hard to obtain onboard by using basic mathematics, however due to the variation in swell, wind, waves, and other factors it is very difficult to determine the optimum constant speed the vessel will have to maintain.

Usually the captain would have chosen route A using Azores as a safe haven in case of bad storms in the North Atlantic, however due to the information readily available to him, he decided it was safe to use route $A$.

By doing so the amount of fuel saved was $42.5 \mathrm{Mt}$ (as opposed to the amount estimated by SPOS 44.9Mt) and 63 hours (2 days and 15 hours) - > $16 \%$ fuel economy. Also using the estimate provided by the software the captain can choose were to fuel, so the bunkering can be done in areas with cheaper fuel, saving more money.

Last but not least, by using route $B$ the ship stayed away from the SECA area, not having to use expensive fuel oil and the vessel did not have to cross the English Channel which would imply further expenses.

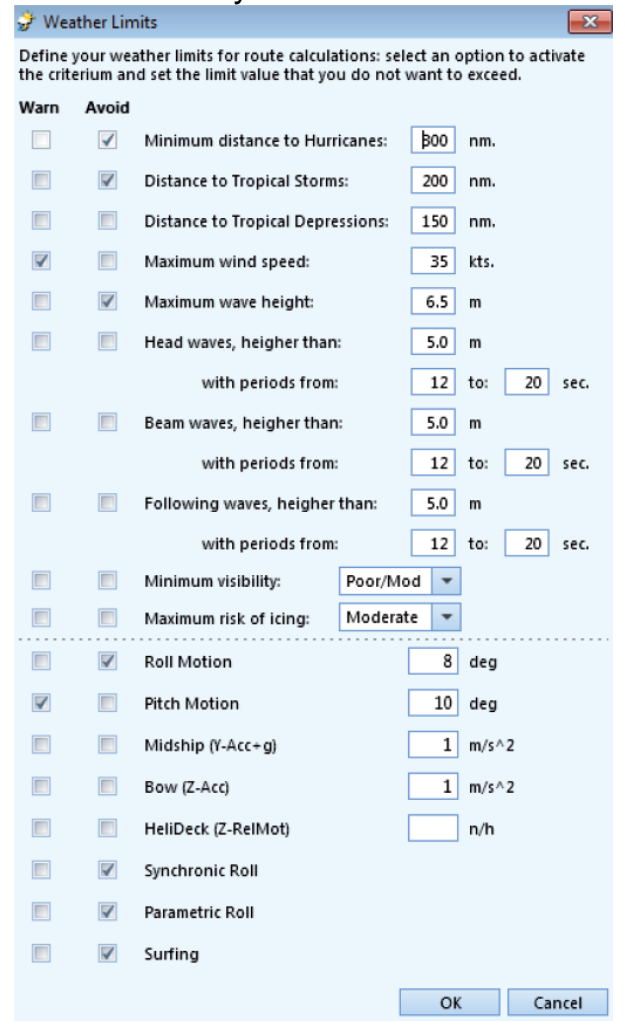

Figure 9 - "Weather Limits" window

\subsection{Case study - GioiaTauro Italy to Valencia Spain}

In the previous example the main objective of the vessel was to avoid storms and have an economic voyage on a very long route (almost 16 days). It chose the certain RPM also considering that the vessel Waste Heat Recovery System had a critical minimum RPM in order to function. Although the engine could have run at slower speed, by engaging the WHRS the vessel was 
"Mircea cel Batran" Naval Academy Scientific Bulletin, Volume XIX - 2016 - Issue 1

Published by "Mircea cel Batran" Naval Academy Press, Constanta, Romania /I The journal is indexed in: PROQUEST / DOAJ I DRJI / JOURNAL INDEX I I2OR / SCIENCE LIBRARY INDEX / Google Scholar / Crossref I

Academic Keys / ROAD Open Access / OAJI / Academic Resources / Scientific Indexing Services / SCIPIO

able to use its exhaust gases in order to produce electricity for the vessel. This way there was no need for expensive diesel generators to run during the long voyage.

In this second case study we will analyze the advantage of SPOS if a vessel has to reach a destination in a very short period of time. In this case we are first of all interested in our ETA. Usually the ship will have a given time to reach its next harbor, and sometimes in case the next port of call is very close, any small delay will have a large impact on the average speed. By using SPOS the Captain will determine the optimum speed / required RPM in order to keep the schedule as planned (Figure 10). At high speed and on small distances the route optimization due to hydro-meteorological parameters will be almost imperceptible, and so will be the fuel efficiency. In this particular case the speed and course will only be reduced by 2\% (Figure 11), for a speed of 18 Kts and 86-87 RPM.

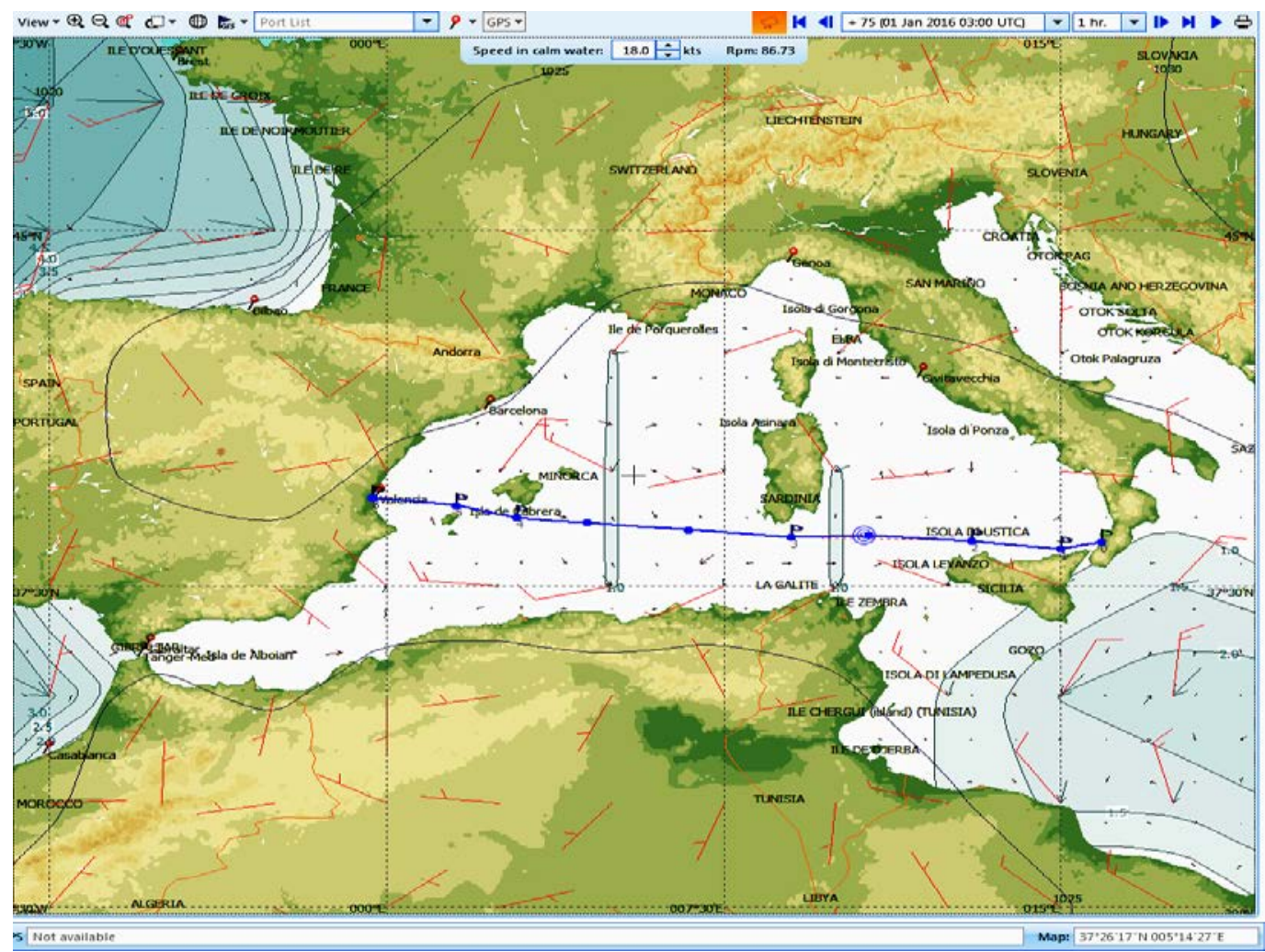

Figure 10 - Route from GioiaTauro to Valencia (speed $18 \mathrm{Kts}$ ) 
"Mircea cel Batran" Naval Academy Scientific Bulletin, Volume XIX - 2016 - Issue 1 Published by "Mircea cel Batran" Naval Academy Press, Constanta, Romania // The journal is indexed in: PROQUEST / DOAJ / DRJI / JOURNAL INDEX / I2OR / SCIENCE LIBRARY INDEX / Google Scholar / Crossref I Academic Keys / ROAD Open Access / OAJI / Academic Resources / Scientific Indexing Services / SCIPIO

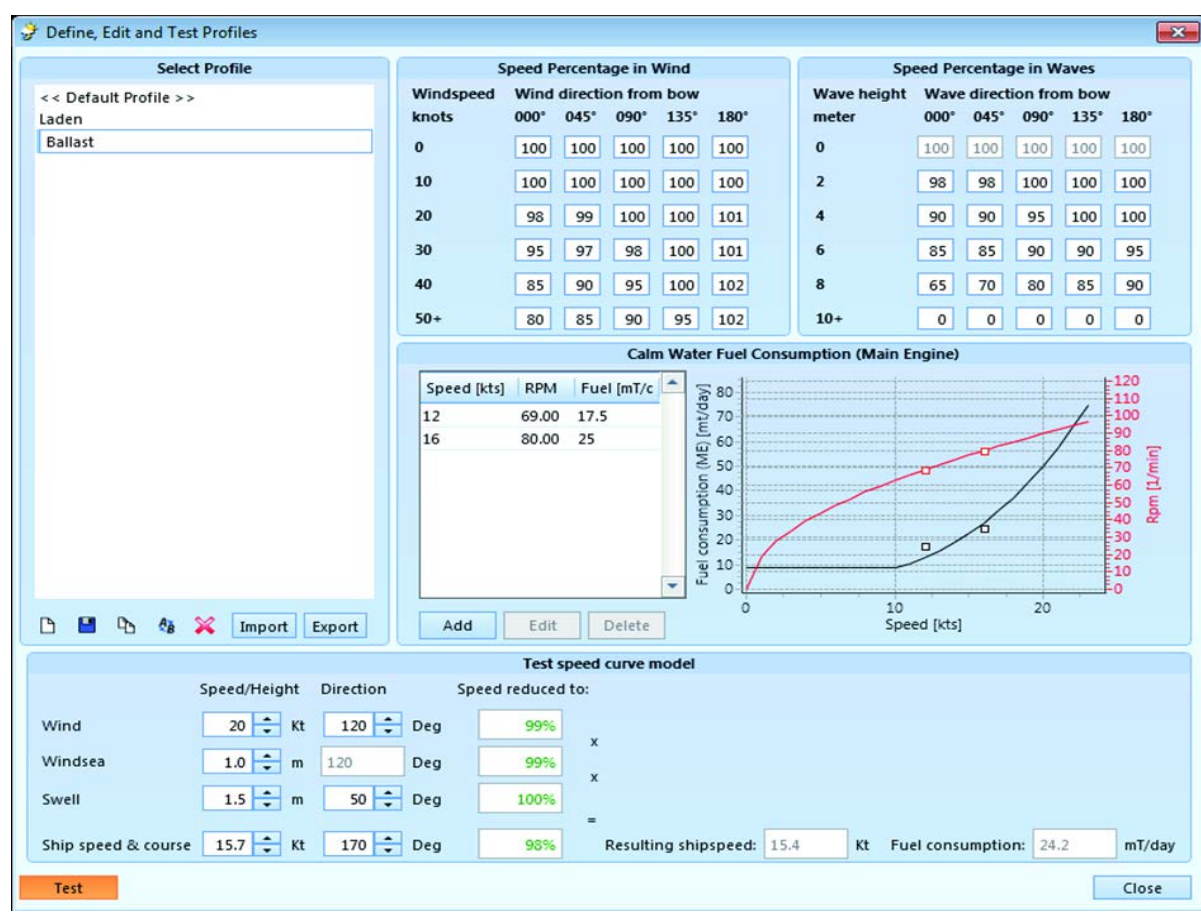

Figure 11 - Test speed curve model

\section{Evaluation of the information obtained from} the software

As with any weather forecasting tool there will always be some room for error. If in the second case the errors are so small it is hard to determine them exactly, in the first case however, we can see that the software predicted the ship to consume $2.4 \mathrm{Mt}$ less than it actually did. Although 2400 liters of fuel on shore seem much, keep in mind that for our route, the error was of only $0.9 \%$. The algorithm used to obtained such a level of precision is very complicated, involving many variables and is kept by the company as a proprietary research. For the purpose of our paper we will use a much more simplified version of it (Formula 1 [6]) written bellow.

$$
\mathrm{V}=\mathrm{V}_{0}-(0.745 \mathrm{~h}-0.257 \mathrm{qh})\left(1.0-1.35 \times 10^{-6} \mathrm{DV}_{0}\right)(1)
$$

where:

$\mathrm{V}$ - the actual speed in the sea

$\mathrm{V}_{0}-$ the speed in calm water

$\mathrm{h}$ - the wave height

$\mathrm{q}$ - the angle between ship heading and wave direction

D - the actual displacement of the ship (tons)

According to Motte et al., 1988 this formula has a very high degree of accuracy for vessels with displacements ranging from 5000 to 25000 tons, speeds between 9 and 20 knots, with waves of 0 5 meters in height.[7][8]

The influence of sea conditions on the ship can be seen in Figure 12
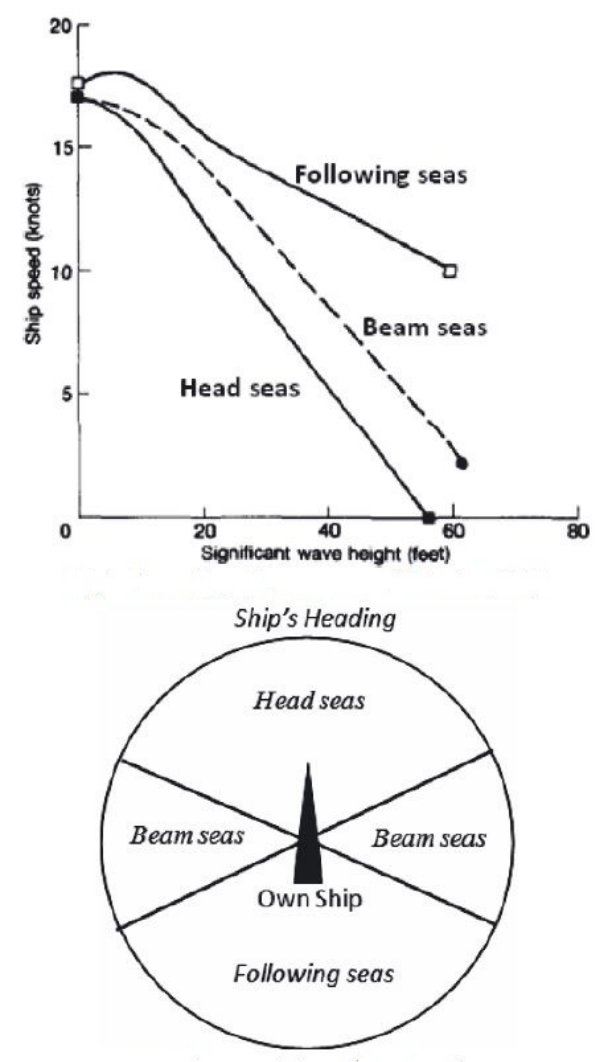

Figure 12 - Ship performance curve and ship orientation and wave direction

\section{CONCLUSIONS}

Weather routing is one of the best way of reducing costs in a very competitive environment. Compared with other technologies capable of reducing fuel consumption, SPOS is very easy to implement and use onboard. 
"Mircea cel Batran" Naval Academy Scientific Bulletin, Volume XIX - 2016 - Issue 1

Published by "Mircea cel Batran" Naval Academy Press, Constanta, Romania /I The journal is indexed in: PROQUEST / DOAJ / DRJI / JOURNAL INDEX / I2OR / SCIENCE LIBRARY INDEX / Google Scholar / Crossref /

Academic Keys / ROAD Open Access / OAJI / Academic Resources / Scientific Indexing Services / SCIPIO

Additionally, it is worth mentioning that considering the new IMO regulation called SEEMP (Figure 13), weather routing fits the given criteria, therefore it will be very easy for charter companies and other investors in the shipping industries to adopt this kind of technology [9]. We also have to consider that all vessels capable of having an early notice about storms or other types of bad weather, will be able to take action and minimize the risks, so premiums on vessel and goods insurances should be lower for customers.

As research has proven in a small scale environment in the Black Sea, intervention in case of distress is possible, but not advisable [10]. For that reason better trained seafarers will help protect the ship, the cargo and the environment.[11]

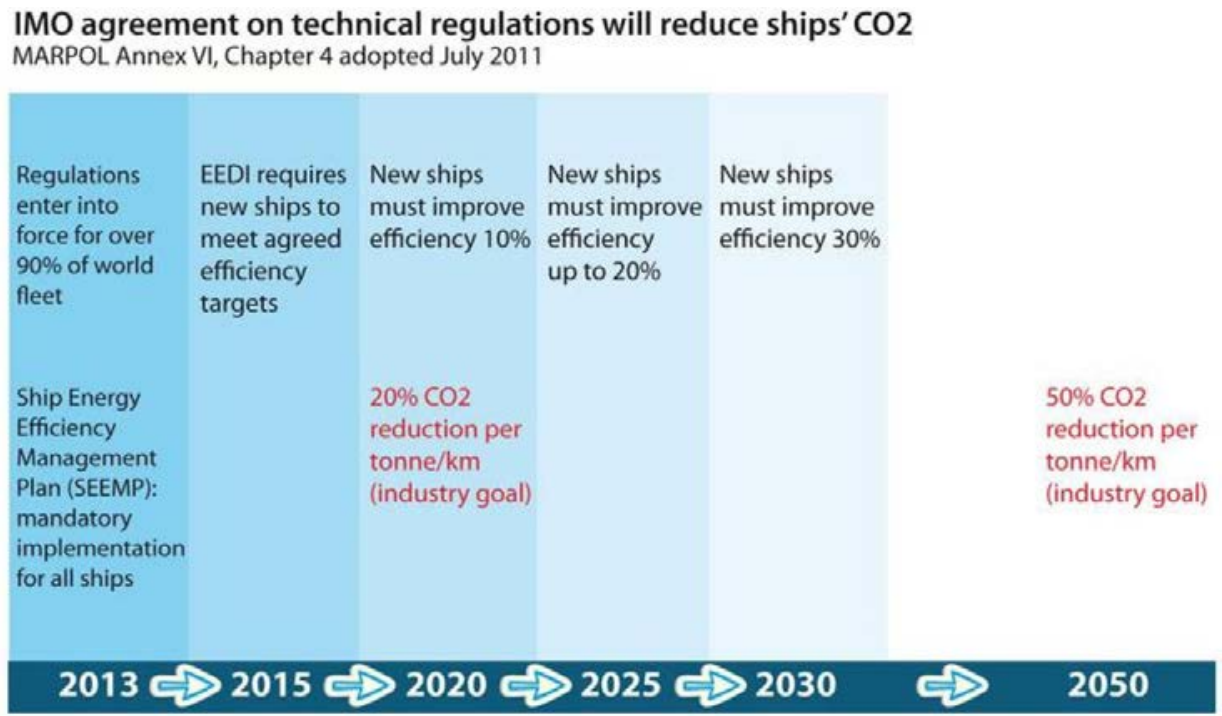

Figure 13 - Implementation of IMO plan to reduce $\mathrm{CO} 2$

We used a calculator to determine animpact of reducing the cost of fuel by $16 \%$ in the figure bellow (Figure 14) [12].

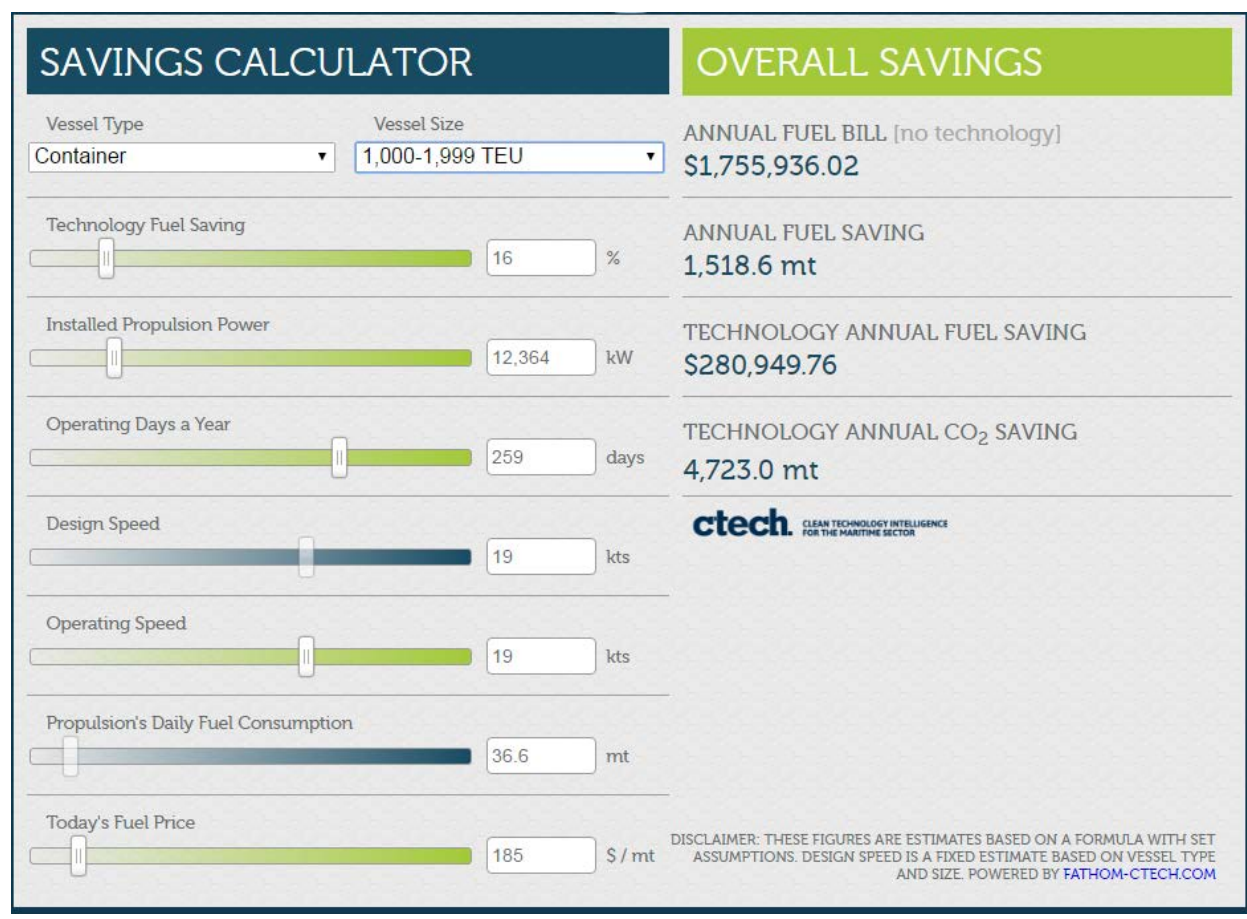

Figure 14 - Saving for the vessel presented at point 3.1 
"MirceacelBatran" Naval Academy Scientific Bulletin, Volume XIX - 2016 - Issue 1

Published by "MirceacelBatran" Naval Academy Press, Constanta, Romania /l The journal is indexed in:

PROQUEST / COPE / DRJI / JOURNAL INDEX / I2OR / SCIENCE LIBRARY INDEX / Google Scholar / Academic Keys / ROAD Open Access / OAJI / Academic Resources / Scientific Indexing Services / SCIPIO

We can see that the impact will be of $\$ 281000$ per year and $4723 \mathrm{Mt}$ of CO2 for one small vessel. The shipping companies will use SPOS or some other software, but weather routing optimization is a "must" of the future.

\section{BIBLIGRAPHY}

[1] http://www.hellenicshippingnews.com/bunker-fuels-account-for-70-of-a-vessels-voyage-operatingcost/ - Research and Markets Corporation

[2] U.S. Environmental Protection Agency - Office of Transportation and Air Quality, July 2011 - Adoption of an Energy Efficiency Design Index for International Shipping , Washington D.C., U.S.A.

[3] U.S. Energy Information Administration, 2015 - Annual Energy Outlook 2015, Washington D.C., U.S.A.

[4] Elliot H.G. 2010 , Limited Downside for Oil Prices, New York, U.S.A.

[5] Lupu S, Toma. A, Pocora A, April 2014, Software application for officers in charge of a navigational watch, ISSN 2360-2198, ISSN-L 2360-2198, Bucharest, Romania

[6] Tsou M.C., Cheng H.C., 2013 - An Ant Colony Algorithm for efficient ship routing, Poland, Vol 20, pp. 28-38

[7] Motte, R. Burns, R. S. and Calvert, S.: An Overview of Current Methods Used in Weather Routeing. The Journal of Navigation, Vol. 41, No. 1, pp. 101-114, 1988.

[8] Smierzchalski, R., Michalewicz, Z.: Modeling of ship trajectory in collision situations by an evolutionary algorithm. IEEE Transactions On Evolutionary Computation, Vol. 4, pp. 227-241, 2000.

[9] Information about SEEMP. (2013, January 16), from ABS Environmental Programs: http://www.namepa.net/ 2013namepa/TomKirk.pdf

[10] Chitac V, Toma A, 2014, Integrated management system for intervention in maritime accidents and distress situations on the Black Sea, ISSN 1454-864X

[11] Lupu S, Toma A., Pocora. A, 2013, Training and evaluation of the seagoing personnel in the "MirceacelBatran" Naval Academy, ISSN 2066-8821

[12] http://shippingefficiency.org/resources\#tools 